Letter to the Editor

\title{
Response to 'Assessing the carbon footprint of beef cattle in Brazil: a case study with 22 farms in the State of Mato Grosso'
}

\begin{abstract}
A B S T R A C T
The recent article in this journal of Cerri et al. (2016) gives estimates of greenhouse gas (GHG) emissions for cattle production on extensively managed farms in the State of Mato Grosso, Brazil. The results are expressed as GHG emission per $\mathrm{kg}$ of animal in the herd, and not per $\mathrm{kg}$ of product. These estimates should not be referred to as "carbon footprints" as they do not reflect the estimate of the GHG emissions utilized in the production of $1 \mathrm{~kg}$ of animal or carcass, but the total emission per $\mathrm{kg}$ of the total mass of animals in the herd, whether calves, heifers, steers or mature bulls and cows. This leads to a large underestimation of the true GHG emissions for the production of Brazilian beef.
\end{abstract}

() 2016 Elsevier Ltd. All rights reserved.
The recent article of Cerri et al. (2016) purports to show that the carbon footprints (total GHG emissions per kg product) for extensive beef production estimated for 22 ranches in the State of Mato Grosso, are between 4.8 and $8.2 \mathrm{~kg} \mathrm{CO} \mathrm{CO}_{2} \mathrm{eq} \mathrm{kg}$ of live weight gain, equivalent to 9.02 and $15.9 \mathrm{~kg} \mathrm{CO}_{2}$ eq per $\mathrm{kg}$ of carcass weight, respectively. As the authors acknowledge these values are far lower than recent estimates made in southern Brazil by Ruviaro et al. (2015) and Dick et al. (2015), and also for different beef-on-pasture production systems in the Cerrado region estimated by Cardoso et al. (2016). These values are also considerably lower than three studies cited by the authors from the USA, France and Australia. In the review of Crosson et al. (2011) most values given in 34 studies from 15 publications are above $20 \mathrm{~kg} \mathrm{CO} 2 \mathrm{eq}$ per $\mathrm{kg}$ of carcass weight, and almost all are systems more intensively managed than the free ranging pasture systems in Mato Grosso.

Cerri et al. (2016) calculated the total emissions for each farm/ herd using entirely appropriate techniques (improved Tier 1 for methane emissions, direct Tier 1 for nitrous oxide emissions and detailed LCA accounting for fossil $\mathrm{CO}_{2}$ emissions). However, when they calculated the "carbon footprint" the authors divided the total GHG emissions in $\mathrm{CO}_{2}$ eq by the total herd weight and not the weight gain, which is obviously far smaller. We show in Table 1 the calculations which lead to the total herd weight for each farm and data on total GHG emissions per herd from Tables 5 and 6 of Cerri et al. (2016). The final column of data are those given by the authors as $\mathrm{kg} \mathrm{CO}_{2} \mathrm{eq} \mathrm{kg} \mathrm{live} \mathrm{weight}{ }^{-1}$ and the values in the penultimate column are our calculations from dividing total GHG emission per herd by the total weight of the herd. We did not have access to the original data but the similarity between our results and that of Cerri et al. (2016) show that the same procedure was adopted. The units given by the authors $\left(\mathrm{kg} \mathrm{CO} \mathrm{CO}_{2} \mathrm{eq} \mathrm{kg}\right.$ live weight $^{-1}$ ) are quite correct, but these values are not a "carbon footprint" as they are not expressed as $\mathrm{kg}$ of product exported from the farm, which would be per live weight gain or per $\mathrm{kg}$ carcass. In the Abstract and the Conclusion the authors state that "the carbon footprints ranged from 4.8 to $8.2 \mathrm{~kg}$ (or 5.0 to $7.2 \mathrm{~kg}$ ) of $\mathrm{CO}_{2} \mathrm{eq}$ per $\mathrm{kg}$ of live weight gain", while the results are in fact per $\mathrm{kg}$ total animal weight. They refer many times in the text that their results are for carbon footprint and even calculate the emission per weight of carcass even though this represents the total carcass weight of all animals in the field, not those exported for sale.

Our concern is that government policy makers and others may use these erroneous results as emissions data for beef or carcass production in Brazil, totally underestimating much more realistic estimations published recently by Dick et al. (2015), Ruviaro et al., 2015 and Cardoso et al. (2016). 
Table 1

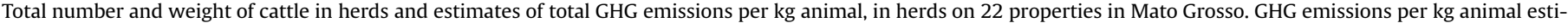
mated by the authors from mean data and original estimates published by Cerri et al. (2016).

\begin{tabular}{|c|c|c|c|c|c|c|c|c|c|c|}
\hline \multirow{3}{*}{$\begin{array}{l}\text { Farm } \\
\text { number }\end{array}$} & \multicolumn{2}{|c|}{ Non-dairy cow } & \multicolumn{2}{|l|}{ Bull } & \multicolumn{2}{|c|}{ Young animals } & \multirow{3}{*}{$\begin{array}{l}\frac{\text { Herd weight }}{\text { Total live }} \\
\text { weight }(\mathrm{Mg})\end{array}$} & \multirow{3}{*}{$\begin{array}{l}\text { Total GHG } \\
\text { Emissions } \\
\left(\mathrm{Mg} \mathrm{CO}_{2} \text { eq herd }\right. \\
\end{array}$} & \multicolumn{2}{|c|}{ GHG emission/animal } \\
\hline & \multirow[t]{2}{*}{ Number } & \multirow{2}{*}{$\begin{array}{l}{ }^{\mathrm{a}} \text { Total } \\
\text { weight }(\mathrm{kg})\end{array}$} & \multirow[t]{2}{*}{ Number } & \multirow{2}{*}{$\begin{array}{l}{ }^{\mathrm{a}} \text { Total } \\
\text { weight }(\mathrm{kg})\end{array}$} & \multirow[t]{2}{*}{ Number } & \multirow{2}{*}{$\begin{array}{l}{ }^{\mathrm{a}} \text { Total } \\
\text { weight (kg) }\end{array}$} & & & Calculated & Original \\
\hline & & & & & & & & & \multicolumn{2}{|c|}{ kg CO2eq. kg animal ${ }^{-1}$} \\
\hline \multicolumn{11}{|l|}{ Group 1} \\
\hline 1 & 938 & 309,540 & 566 & 215,080 & 438 & 100,740 & 625.36 & 4017.39 & 6.42 & 6.00 \\
\hline 2 & 244 & 80,520 & 0 & 0 & 729 & 167,670 & 248.19 & 1846.85 & 7.44 & 8.20 \\
\hline 3 & 894 & 295,020 & 527 & 200,260 & 33 & 7590 & 502.87 & 3481.79 & 6.92 & 6.07 \\
\hline 4 & 292 & 96,360 & 150 & 57,000 & 716 & 164,680 & 318.04 & 2025.64 & 6.37 & 6.72 \\
\hline 5 & 553 & 182,490 & 9 & 3420 & 311 & 71,530 & 257.44 & 1730.26 & 6.72 & 6.84 \\
\hline 6 & 80 & 26,400 & 39 & 14,820 & 64 & 14,720 & 55.94 & 363.14 & 6.49 & 7.04 \\
\hline 7 & 0 & 0 & 470 & 178,600 & 0 & 0 & 178.6 & 966.15 & 5.41 & 4.78 \\
\hline 8 & 531 & 175,230 & 47 & 17,860 & 496 & 114,080 & 307.17 & 1988.67 & 6.47 & 6.80 \\
\hline 9 & 592 & 195,360 & 84 & 31,920 & 260 & 59,800 & 287.08 & 1873.92 & 6.53 & 6.40 \\
\hline 10 & 500 & 165,000 & 3 & 1140 & 58 & 13,340 & 179.48 & 1290.57 & 7.19 & 5.83 \\
\hline 11 & 7 & 2310 & 600 & 228,000 & 320 & 73,600 & 303.91 & 1707.93 & 5.62 & 5.56 \\
\hline \multicolumn{11}{|l|}{ Group 2} \\
\hline 12 & 1093 & 360,690 & 372 & 141,360 & 1139 & 261,970 & 764.02 & 4778.26 & 6.25 & 6.46 \\
\hline 13 & 3000 & 990,000 & 1301 & 494,380 & 1586 & 364,780 & 1849.16 & $11,732,92$ & 6.34 & 6.03 \\
\hline 14 & 3050 & $1,006,500$ & 2827 & $1,074,260$ & 1524 & 350,520 & 2431.28 & 14,905 & 6.13 & 5.76 \\
\hline 15 & 1728 & 570,240 & 63 & 23,940 & 1488 & 342,240 & 936.42 & 6284.14 & 6.71 & 6.84 \\
\hline 16 & 8095 & $2,671,350$ & 2675 & $1,016,500$ & 4539 & $1,043,970$ & 4731.82 & $31,887,69$ & 6.74 & 5.51 \\
\hline 17 & 2000 & 660,000 & 60 & 22,800 & 1500 & 345,000 & 1027.8 & 6598.43 & 6.42 & 6.87 \\
\hline 18 & 3446 & $1,137,180$ & 1279 & 486,020 & 1275 & 293,250 & 1916.45 & $12,264,69$ & 6.40 & 5.93 \\
\hline 19 & 2448 & 807,840 & 278 & 105,640 & 1588 & 365,240 & 1278.72 & 9193.59 & 7.19 & 7.15 \\
\hline 20 & 0 & 0 & 6087 & $2,313,060$ & 0 & 0 & 2313.06 & $12,467,35$ & 5.39 & 4.97 \\
\hline 21 & 1357 & 447,810 & 1643 & 624,340 & 2058 & 473,340 & 1545.49 & 9619.48 & 6.22 & 6.33 \\
\hline 22 & 1400 & 462,000 & 3000 & $1,140,000$ & 4500 & $1,035,000$ & 2637 & $15,317,93$ & 5.81 & 6.24 \\
\hline
\end{tabular}

${ }^{\text {a }}$ Calculated from mean of range of animal weights given in column headings of Table 2 of Cerri et al. (2016).

\section{References}

Cerri, C.C., Silva Moreira, C., Alves, P.A., Raucci, G.S., Castigioni, B. de A., Mello, F.F.C. Cerri, D.G.P., Cerri, C.E.P., 2016. Assessing the carbon footprint of beef cattle in Brazil: a case study with 22 farms in the State of Mato Grosso. J. Clean. Prod. $112,2593-2600$

Cardoso, A.S., Berndt, A., Leytem, A., Alves, B.J.R., de Carvalho, I. das N.O., de Barros Soares, L.H., Urquiaga, S., Boddey, R.M., 2016. Impact of the intensification of beef production in Brazil on greenhouse gas emissions and land use. Agric. Syst. 143, 86-96.

Crosson, P., Shalloo, L., O'Brien, D., Lanigan, G.J., Foley, P.A., Boland, T.M., 2011. A review of whole farm systems models of greenhouse gas emissions from beef and dairy cattle production systems. Anim. Feed Sci. Tech. 166-167, 29-45.

Dick, M., Silva, M.A., Dewes, H., 2015. Life cycle assessment of beef cattle production in two typical grassland systems of southern Brazil. J. Clean. Prod. 96, 426-434.
Ruviaro, C.F., de Léis, C.M., Lampert, V.N., Barcellos, J.O.J., Dewes, H., 2015. Carbon footprint in different beef production systems on a southern Brazilian farm: a case study. J. Clean. Prod. 96, 435-443.

Robert M. Boddey*, Abmael S. Cardoso ${ }^{1}$, Bruno J.R. Alves Embrapa-Agrobiologia, Rodovia BR 465, km 07, Seropédica, RJ, 23891-000, Brazil

* Corresponding author. E-mail address: robert.boddey@embrapa.br (R.M. Boddey).

27 January 2016 Available online 13 February 2016

\footnotetext{
1 Present address: Departamento de Zootecnia, Faculdade de Ciências Agrárias e Veterinárias, UNESP, 14884-900, Jaboticabal, SP, Brazil.
} 